\title{
Surgery for aortic dilatation in patients with bicuspid aortic valves
}

A statement of clarification from the American College of Cardiology/American Heart Association Task Force on Clinical Practice Guidelines

Endorsed by the American College of Radiology, The American Association for Thoracic Surgery, American Society of Echocardiography, American Stroke Association, Society for Cardiovascular Angiography and Interventions, Society of Cardiovascular Anesthesiologists, Society of Interventional Radiology, Society of Thoracic Surgeons, and the Society for Vascular Medicine

\section{ACCF/ AHA/AATS/ACR/ ASA/SCA/SCAI/ SIR/STS/SVM Guidelines for the Diagnosis and Management of Patients With Thoracic Aortic Disease Representative Members*:}

2014 AHA/ACC Guideline for the Management of Patients With Valvular Heart Disease Representative Members*:
Loren F. Hiratzka, MD, FACC, FAHA, Chair, Mark A. Creager, MD, FACC, FAHA, $\dagger$

Eric M. Isselbacher, MD, FACC, and Lars G. Svensson, MD, PhD, FACC
Rick A. Nishimura, MD, MACC, FAHA, Chair, Robert O. Bonow, MD, MACC, FAHA, Robert A. Guyton, MD, FACC, $\dagger$ and Thoralf M. Sundt III, MD, FACC, FAHA

\footnotetext{
*Writing committee members are required to recuse themselves from voting on sections to which their specific relationships with industry and other entities may apply; see Appendix 1 for recusal information. $\nmid$ ACC/AHA Task Force on Clinical Practice Guidelines Liaison. †FFormer Task Force member; current member during this writing effort.

This document was approved by the American College of Cardiology Board of Trustees and Executive Committee, the American Heart Association Science Advisory and Coordinating Committee and the American Heart Association and Executive Committee in August 2015, and by the TAD partner organizations (AATS/ACR/ASA/SCA/SCAI/SIR/STS/SVM).

The online-only comprehensive table of author relationships with industry and other entities is available at http://jaccjacc.acc.org/Clinical_Document/TAD_VHD_ Guideline_Clarification_Author_Comprehensive_RWI_Table.doc.

The American College of Cardiology Foundation requests that this document be cited as follows: Hiratzka LF, Nishimura RA, Bonow RO, Creager MA, Guyton RA, Isselbacher EM, Sundt TM 3rd, Svensson LG. Surgery for aortic dilatation in patients with bicuspid aortic valves: a statement of clarification from the American College of Cardiology/American Heart Association Task Force on Clinical Practice Guidelines. J Am Coll Cardiol. 2016;67:724-31.
}

This article has been copublished in Circulation and Journal of the American College of Cardiology. Reprinted in the The Journal of Thoracic and Cardiovascular Surgery and Vascular Medicine with permission of the American College of Cardiology Foundation and the American Heart Association.

Copies: This document is available on the World Wide Web sites of the American College of Cardiology (www.acc.org) and the American Heart Association (my. americanheart.org). For copies of this document, please contact Elsevier Inc. Reprint Department, fax: (212) 633-3820 or E-mail: reprints@elsevier.com.

Permissions: Multiple copies, modification, alteration, enhancement, and/or distribution of this document are not permitted without the express permission of the American College of Cardiology Foundation. Requests may be completed online via the Elsevier site (http://www.elsevier.com/about/policies/author-agreement/ obtaining-permission).

J Thorac Cardiovasc Surg 2016;151:959-66 $0022-5223 / \$ 36.00$

(C) 2016 by the American College of Cardiology Foundation and American Heart Association, Inc.

http://dx.doi.org/10.1016/j.jtcvs.2015.12.001 


\author{
ACC/AHA Task \\ Jonathan L. Halperin, MD, FACC, FAHA, Chair, \\ Force Members: \\ Glenn N. Levine, MD, FACC, FAHA, Chair-Elect, \\ Jeffrey L. Anderson, MD, FACC, FAHA, Immediate Past Chair $\ddagger$ \\ Nancy M. Albert, PhD, RN, FAHA, $\ddagger$ Mark A. Hlatky, MD, FACC, \\ Sana M. Al-Khatib, MD, MHS, FACC, FAHA, John Ikonomidis, MD, PhD, FAHA, \\ Kim K. Birtcher, PharmD, AACC, José Joglar, MD, FACC, FAHA, \\ Biykem Bozkurt, MD, PhD, FACC, FAHA, Richard J. Kovacs, MD, FACC, FAHA, \\ Ralph G. Brindis, MD, MPH, MACC, E. Magnus Ohman, MD, FACC, \\ Joaquin E. Cigarroa, MD, FACC, Susan J. Pressler, PhD, RN, FAHA, \\ Lesley H. Curtis, PhD, FAHA, Frank W. Sellke, MD, FACC, FAHA, \\ Lee A. Fleisher, MD, FACC, FAHA, Win-Kuang Shen, MD, FACC, FAHA, \\ Federico Gentile, MD, FACC, Duminda N. Wijeysundera, MD, PhD, and \\ Samuel Gidding, MD, FAHA
}

\begin{abstract}
Two guidelines from the American College of Cardiology (ACC), the American Heart Association (AHA), and collaborating societies address the risk of aortic dissection in patients with bicuspid aortic valves and severe aortic enlargement: The "2010 ACCF/AHA/AATS/ACR/ASA/SCA/SCAI/SIR/STS/SVM Guidelines for the Diagnosis and Management of Patients With Thoracic Aortic Disease" (J Am Coll Cardiol. 2010;55:e27-130) and the "2014 AHA/ACC Guideline for the Management of Patients With Valvular Heart Disease" ( $\mathrm{J}$ Am Coll Cardiol. 2014;63:e57-185). However, the 2 guidelines differ with regard to the recommended threshold of aortic root or ascending aortic dilatation that would justify surgical intervention in patients with bicuspid aortic valves. The ACC and AHA therefore convened a subcommittee representing members of the 2 guideline writing committees to review the evidence, reach consensus, and draft a statement of clarification for both guidelines. This statement of clarification uses the ACC/AHA revised structure for delineating the Class of Recommendation and Level of Evidence to provide recommendations that replace those contained in Section 9.2.2.1 of the thoracic aortic disease guideline and Section 5.1.3 of the valvular heart disease guideline.
\end{abstract} See Editorial Commentary page 967.

The association between bicuspid aortic valve (BAV) and dilatation of the aortic root and ascending aorta is well established, as is the risk of aortic dissection in patients with $\mathrm{BAV}$ and severe aortic enlargement. However, data are limited with regard to the aortic diameter at which the risk of dissection is high enough to warrant operative intervention in patients who do not otherwise fulfill criteria for aortic valve replacement (AVR) on the basis of severe aortic stenosis or aortic regurgitation. Two guidelines from the American College of Cardiology/American Heart Association (ACC/ AHA) and collaborating societies differed with regard to the recommended threshold of aortic root or ascending aortic dilatation that would justify surgical intervention in such patients. ${ }^{1,2}$ A subcommittee representing members of the 2 writing committees, which met current organizational policies for disclosure of relationships with industry (Appendix 1), was convened to review the evidence, reach consensus, and draft the present statement as an addendum to both guidelines. The evidence table to support this addendum is available as an Online Data Supplement. This statement was approved by the 2 guideline writing committees, underwent peer review (Appendix 2), and received formal approval by the ACC and AHA and endorsements by partner/collaborating organizations. The following recommendations replace those contained in Sections 9.2.2.1 and 5.1.3, respectively, of the original guideline ${ }^{1,2}$ and use the revised structure for delineating the Class of Recommendation and Level of Evidence adopted by the ACC/AHA Task Force on Clinical Practice Guidelines ${ }^{3}$ (Table 1, Recommendations Table, Table 2). 
TABLE 1. Applying class of recommendation and level of evidence to clinical strategies, interventions, treatments, or diagnostic testing in patient care* (updated August 2015)

\begin{tabular}{l} 
CLASS (STRENGTH) OF RECOMMENDATION \\
\hline CLASS I (SIRONG) Bencift $\gg \gg$ Risk \\
\hline Suggested phrases for writing recommendations: \\
- Is recommended \\
- Is indicated/useful/effective/beneficial \\
- Should be performed/administered/other \\
- Comparative-Effectiveness Phrasest: \\
○ Treatment/strategy A is recommended/indicated in \\
o preference to treatment B
\end{tabular}

C.ASS lla (MOD ERAIIs)
Suggested phrases for writing recommendations:
- Is reasonable
- Can be useful/effective/beneficial
- Comparative-Effectiveness Phrasest:
- Treatment/strategy A is probably recommended/indicated in
preference to treatment B
o It is reasonable to choose treatment A
over treatment B

CLASS Ilb (WEAK)
Suggested phrases for writing recommendations:
- May/might be reasonable
- May/might be considered
- Usefulness/effectiveness is unknown/unclear/uncertain
or not well established

CLASS III: No Benefit (MODERATE) Benefit = Risk
(Generally, LOE A or B use only)

Suggested phrases for writing recommendations:

- Is not recommended

- Is not indicated/useful/effective/beneficial

- Should not be performed/administered/other

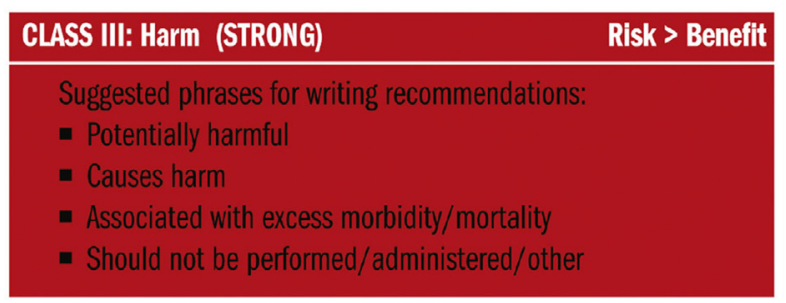

\section{LEVEL (QUALITY) OF EVIDENCE‡}

\begin{tabular}{l} 
LEVEL A \\
\hline - High-quality evidenceł from more than 1 RCT \\
- Meta-analyses of high-quality RCTs \\
- One or more RCTs corroborated by high-quality registry studies
\end{tabular}

LEVEL B-R (Reandomized)

- Moderate-quality evidenceł from 1 or more RCTs

- Meta-analyses of moderate-quality RCTs

LEVEL B-NR

(Nonrandomized)

- Moderate-quality evidenceł from 1 or more well-designed, well-executed nonrandomized studies, observational studies, or registry studies

- Meta-analyses of such studies

LEVIEL C-LD

(Limited Data)

- Randomized or nonrandomized observational or registry studies with limitations of design or execution

- Meta-analyses of such studies

- Physiological or mechanistic studies in human subjects

LEVEL C-EO

(Expert Opinion)

Consensus of expert opinion based on clinical experience

COR and LOE are determined independently (any COR may be paired with any LOE).

A recommendation with $\mathrm{LOE} C$ does not imply that the recommendation is weak. Many important clinical questions addressed in guidelines do not lend themselves to clinical trials. Although RCTs are unavailable, there may be a very clear clinical consensus that a particular test or therapy is useful or effective.

* The outcome or result of the intervention should be specified (an improved clinical outcome or increased diagnostic accuracy or incremental prognostic information).

† For comparative-effectiveness recommendations (COR I and Ila; LOE A and B only), studies that support the use of comparator verbs should involve direct comparisons of the treatments or strategies being evaluated.

$\ddagger$ The method of assessing quality is evolving, including the application of standardized, widely used, and preferably validated evidence grading tools; and for systematic reviews, the incorporation of an Evidence Review Committee.

COR indicates Class of Recommendation; EO, expert opinion; LD, limited data; LOE, Level of Evidence; NR, nonrandomized; R, randomized; and RCT, randomized controlled trial. 
Intervention in Patients With BAV and Dilatation of the Aortic Root (Sinuses) or Ascending Aorta: Recommendations

\begin{tabular}{|c|c|c|}
\hline COR & LOE & Recommendations \\
\hline I & B-NR & $\begin{array}{l}\text { 1. Operative intervention to repair or replace the aortic root (sinuses) or replace the ascending aorta is indicated in } \\
\text { asymptomatic patients with BAV if the diameter of the aortic root or ascending aorta is } 5.5 \mathrm{~cm} \text { or greater. } .^{4-8}\end{array}$ \\
\hline \multicolumn{2}{|c|}{ See Online Data Supplement. } & $\begin{array}{l}\text { There is uncertainty about whether patients with BAV should undergo aortic repair at diameters smaller than those } \\
\text { recommended for patients with ascending aortic aneurysms in the setting of a tricuspid aortic valve. Both the histology and } \\
\text { mechanical properties of the ascending aorta differ between those with BAV and those with tricuspid aortic valves, raising the } \\
\text { possibility that the aortic wall may be more vulnerable to dissection in those with BAV. }{ }^{4-6} \text { Conversely, among patients presenting } \\
\text { with acute type A aortic dissection, the mean diameter of the aortic root or ascending aorta may actually be greater in those } \\
\text { with BAV than in those with tricuspid valves. }{ }^{7.8} \text { Such conflicting evidence and the lack of sufficient prospective observational or } \\
\text { randomized trial data create uncertainty about the diameter at which aortic root or ascending aortic repair should be performed } \\
\text { in those with BAV. There is broad agreement, however, that those with aortic root or ascending aortic aneurysms, regardless of } \\
\text { etiology, merit surgical repair when the aortic diameter is } \geq 5.5 \mathrm{~cm} \text {, and this threshold should apply to those with BAV as well. }\end{array}$ \\
\hline Ila & B-NR & $\begin{array}{l}\text { 1. Operative intervention to repair or replace the aortic root (sinuses) or replace the ascending aorta is reasonable in } \\
\text { asymptomatic patients with BAV if the diameter of the aortic root or ascending aorta is } 5.0 \mathrm{~cm} \text { or greater and an } \\
\text { additional risk factor for dissection is present (eg, family history of aortic dissection or aortic growth rate } \geq 0.5 \mathrm{~cm} \\
\text { per year) or if the patient is at low surgical risk and the surgery is performed by an experienced aortic surgical team } \\
\text { in a center with established expertise in these procedures., }{ }^{2,-9}\end{array}$ \\
\hline \multicolumn{2}{|c|}{ See Online Data Supplement. } & $\begin{array}{l}\text { In patients determined to have higher risk of dissection on the basis of family history or rapid aortic expansion ( } \geq 0.5 \mathrm{~cm} \text { per } \\
\text { year), surgical intervention is reasonable when the aortic diameter reaches } \geq 5.0 \mathrm{~cm} \text {. Patients with BAV tend to present with } \\
\text { aortic dissection at younger ages than patients with tricuspid aortic valves, }{ }^{7-9} \text { and those with large asymptomatic aneurysms } \\
\text { may benefit from prophylactic aortic repair at younger ages than patients with tricuspid aortic valves who have similar- } \\
\text { sized aneurysms. Observational data support operation for patients with aortic root diameter } \geq 5.0 \mathrm{~cm} .{ }^{10} \text { Therefore, repair or } \\
\text { replacement of the aortic root or replacement of the ascending aorta is reasonable when the aortic diameter is } \geq 5.0 \mathrm{~cm} \text { in } \\
\text { patients with BAV who are at low surgical risk according to the "2014 AHA/ACC Guideline for the Management of Patients } \\
\text { With Valvular Heart Disease" (Table 2) }{ }^{2} \text { when the operation is performed by experienced surgeons in centers with established } \\
\text { expertise in these procedures to ensure low risk of morbidity and mortality. Whether the diameter threshold for surgery differs } \\
\text { according to the level of maximum dilatation (aortic sinuses versus ascending aorta) requires further investigation. In short- } \\
\text { statured patients with Turner syndrome and BAV, absolute measurement of aortic root or ascending aortic diameter may not } \\
\text { predict the risk of aortic dissection as well as aortic diameter index } \geq 2.5 \mathrm{~cm} / \mathrm{m}^{2} .{ }^{11,12} \text { In addition, in } 1 \text { study of patients with BAV, } \\
\text { a maximum aortic root cross-sectional area-to-height ratio } \geq 10 \mathrm{~cm}^{2} / \mathrm{m} \text { was also a predictor of aortic dissection. } .^{10}\end{array}$ \\
\hline Ila & C-EO & $\begin{array}{l}\text { 2. Replacement of the ascending aorta is reasonable in patients with BAV undergoing AVR because of severe aortic } \\
\text { stenosis or aortic regurgitation when the diameter of the ascending aorta is greater than } 4.5 \mathrm{~cm} .13-17\end{array}$ \\
\hline \multicolumn{2}{|c|}{$\ldots$} & $\begin{array}{l}\text { For patients with BAV, data are limited with regard to the aortic diameter at which the risk of dissection is high enough to } \\
\text { warrant replacement of the ascending aorta at the time of AVR. The risk of progressive aortic dilatation and dissection after AVR } \\
\text { in patients with BAV has been the subject of several studies, but definitive data are lacking. }{ }^{13-17}\end{array}$ \\
\hline
\end{tabular}


TABLE 2. Risk assessment combining STS risk estimate, frailty, major organ system dysfunction, and procedure-specific impediments

\begin{tabular}{|c|c|c|c|c|}
\hline & $\begin{array}{c}\text { Low risk } \\
\text { (must meet } \\
\text { ALL criteria } \\
\text { in this column) }\end{array}$ & $\begin{array}{l}\text { Intermediate } \\
\text { risk (any } 1 \\
\text { criterion in this } \\
\text { column) }\end{array}$ & $\begin{array}{l}\text { High risk (any } 1 \text { criterion } \\
\text { in this column) }\end{array}$ & $\begin{array}{l}\text { Prohibitive risk } \\
\text { (any } 1 \text { criterion } \\
\text { in this column) }\end{array}$ \\
\hline STS PROM* & $\begin{array}{l}<4 \% \\
\text { AND }\end{array}$ & $\begin{array}{l}4 \%-8 \% \\
\text { OR }\end{array}$ & $\begin{array}{l}>8 \% \\
\text { OR }\end{array}$ & \\
\hline Frailty $\dagger$ & $\begin{array}{l}\text { None } \\
\text { AND }\end{array}$ & $\begin{array}{l}1 \text { Index (mild) } \\
\text { OR }\end{array}$ & $\begin{array}{l}\geq 2 \text { Indices (moderate } \\
\text { to severe) } \\
\text { OR }\end{array}$ & $\begin{array}{l}\text { Predicted risk with } \\
\text { surgery of death or } \\
\text { major morbidity } \\
\text { (all-cause) }>50 \% \text { at } 1 \text { y } \\
\text { OR }\end{array}$ \\
\hline $\begin{array}{l}\text { Major organ system compromise } \\
\text { not to be improved } \\
\text { postoperatively } \ddagger\end{array}$ & $\begin{array}{l}\text { None } \\
\text { AND }\end{array}$ & $\begin{array}{l}1 \text { Organ system } \\
\text { OR }\end{array}$ & $\begin{array}{l}\text { No more than } 2 \text { organ } \\
\text { systems } \\
\text { OR }\end{array}$ & $\begin{array}{l}\geq 3 \text { Organ systems } \\
\text { OR }\end{array}$ \\
\hline Procedure-specific impediment $\S$ & None & $\begin{array}{l}\text { Possible procedure- } \\
\text { specific impediment }\end{array}$ & $\begin{array}{l}\text { Possible procedure-specific } \\
\text { impediment }\end{array}$ & $\begin{array}{c}\text { Severe procedure-specific } \\
\text { impediment }\end{array}$ \\
\hline
\end{tabular}

$C K D$, Chronic kidney disease; $C N S$, central nervous system; $C V A$, cerebrovascular accident (stroke); $D L C o_{2}$, diffusion capacity for carbon dioxide; $F E V_{l}$, forced expiratory volume in $1 \mathrm{~s}$; GI, gastrointestinal; INR, international normalized ratio; $L V$, left ventricular; PROM, predicted risk of mortality; $R V$, right ventricular; $S T S$, Society of Thoracic Surgeons; and VKA, vitamin $\mathrm{K}$ antagonist. *Use of the STS PROM to predict risk in a given institution with reasonable reliability is appropriate only if institutional outcomes are within 1 standard deviation of STS average observed/expected ratio for the procedure in question. †Seven frailty indices: Katz Activities of Daily Living (independence in feeding, bathing, dressing, transferring, toileting, and urinary continence) and independence in ambulation (no walking aid or assist required or 5-m walk in $<6 \mathrm{~s}$ ). Other scoring systems can be applied to calculate no, mild, or moderate-to-severe frailty. $\ddagger$ Examples of major organ system compromise: Cardiac-severe LV systolic or diastolic dysfunction or RV

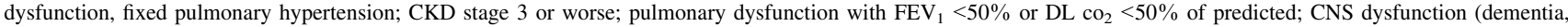
Alzheimer's disease, Parkinson's disease, CVA with persistent physical limitation); GI dysfunction-Crohn's disease, ulcerative colitis, nutritional impairment, or serum albumin $<3.0$; cancer-active malignancy; and liver-any history of cirrhosis, variceal bleeding, or elevated INR in the absence of VKA therapy. $§$ Examples: tracheostomy present, heavily calcified ascending aorta, chest malformation, arterial coronary graft adherent to posterior chest wall, or radiation damage. Reproduced from Nishimura et al.

\section{References}

1. Hiratzka LF, Bakris GL, Beckman JA, et al. 2010 ACCF/AHA/AATS/ACR/ ASA/SCA/SCAI/SIR/STS/SVM guidelines for the diagnosis and management of patients with thoracic aortic disease. A report of the American College of Cardiology Foundation/American Heart Association Task Force on Practice Guidelines, American Association for Thoracic Surgery, American College of Radiology, American Stroke Association, Society of Cardiovascular Anesthesiologists, Society for Cardiovascular Angiography and Interventions, Society of Interventional Radiology, Society of Thoracic Surgeons, and Society for Vascular Medicine [published correction appears in J Am Coll Cardiol. 2013;62:1039-40]. J Am Coll Cardiol. 2010;55:e27-129.

2. Nishimura RA, Otto CM, Bonow RO, et al. 2014 AHA/ACC guideline for the management of patients with valvular heart disease: a report of the American College of Cardiology/American Heart Association Task Force on Practice Guidelines [published correction appears in J Am Coll Cardiol. 2014;63:2489]. J Am Coll Cardiol. 2014;63:e57-185.

3. Jacobs AK, Anderson JL, Halperin JL, et al. The evolution and future of ACC/ AHA clinical practice guidelines: a 30-year journey: a report of the American College of Cardiology/American Heart Association Task Force on Practice Guidelines. J Am Coll Cardiol. 2014;64:1373-84.

4. Fedak PWM, de Sa MPL, Verma S, et al. Vascular matrix remodeling in patients with bicuspid aortic valve malformations: implications for aortic dilatation. J Thorac Cardiovasc Surg. 2003;126:797-806.

5. Grewal N, Gittenberger-de Groot AC, Poelmann RE, et al. Ascending aorta dilation in association with bicuspid aortic valve: a maturation defect of the aortic wall. J Thorac Cardiovasc Surg. 2014;148:1583-90.

6. Pasta S, Phillippi JA, Gleason TG, et al. Effect of aneurysm on the mechanical dissection properties of the human ascending thoracic aorta. J Thorac Cardiovasc Surg. 2012;143:460-7.

7. Eleid MF, Forde I, Edwards WD, et al. Type A aortic dissection in patients with bicuspid aortic valves: clinical and pathological comparison with tricuspid aortic valves. Heart. 2013;99:1668-74.

8. Etz CD, von Aspern K, Hoyer A, et al. Acute type A aortic dissection: characteristics and outcomes comparing patients with bicuspid versus tricuspid aortic valve. Eur J Cardiothorac Surg. 2015;48:142-50.
9. Davies RR, Kaple RK, Mandapati D, et al. Natural history of ascending aortic aneurysms in the setting of an unreplaced bicuspid aortic valve. Ann Thorac Surg. 2007;83:1338-44.

10. Wojnarski CM, Svensson LG, Roselli EE, et al. Aortic dissection in patients with bicuspid aortic valve-associated aneurysms. Ann Thorac Surg. 2015;100: 1666-74.

11. Carlson M, Airhart N, Lopez L, et al. Moderate aortic enlargement and bicuspid aortic valve are associated with aortic dissection in Turner syndrome: report of the International Turner Syndrome Aortic Dissection Registry. Circulation. 2012;126:2220-6.

12. Matura LA, Ho VB, Rosing DR, et al. Aortic dilatation and dissection in Turne syndrome. Circulation. 2007;116:1663-70.

13. Russo CF, Mazzetti S, Garatti A, et al. Aortic complications after bicuspid aortic valve replacement: long-term results. Ann Thorac Surg. 2002; 74:S1773-6.

14. Yasuda H, Nakatani S, Stugaard M, et al. Failure to prevent progressive dilation of ascending aorta by aortic valve replacement in patients with bicuspid aortic valve: comparison with tricuspid aortic valve. Circulation. 2003;108(suppl 1): II291-4.

15. Borger MA, Preston M, Ivanov J, et al. Should the ascending aorta be replaced more frequently in patients with bicuspid aortic valve disease? J Thorac Cardiovasc Surg. 2004;128:677-83.

16. Svensson LG, Kim K-H, Blackstone EH, et al. Bicuspid aortic valve surgery with proactive ascending aorta repair. J Thorac Cardiovasc Surg. 2011;142:622-9. 629.e1-3.

17. Park CB, Greason KL, Suri RM, et al. Fate of nonreplaced sinuses of Valsalva in bicuspid aortic valve disease. J Thorac Cardiovasc Surg. 2011;142: 278-84.

Key Words: AHA Scientific Statements, anticoagulation therapy, heart valves, thoracic aortic aneurysm, thoracic aortic disease, thoracic aortic dissection, valvular heart disease 
APPENDIX 1. Author relationships with industry and other entities (relevant)—surgery for aortic dilatation in patients with bicuspid aortic valves: A statement of clarification from the ACC/AHA Task Force on Clinical Practice Guidelines (December 2014)

\begin{tabular}{|c|c|c|c|c|c|c|c|c|}
\hline Committee member & Employment & Consultant & $\begin{array}{c}\text { Speakers } \\
\text { bureau }\end{array}$ & $\begin{array}{l}\text { Ownership/ } \\
\text { partnership/ } \\
\text { principal }\end{array}$ & $\begin{array}{l}\text { Personal } \\
\text { Research }\end{array}$ & $\begin{array}{l}\text { Institutional, } \\
\text { organizational, } \\
\text { or other } \\
\text { financial } \\
\text { benefit } \\
\end{array}$ & $\begin{array}{l}\text { Expert } \\
\text { witness }\end{array}$ & $\begin{array}{c}\text { Voting } \\
\text { recusals* } \\
\end{array}$ \\
\hline $\begin{array}{l}\text { Loren F. Hiratzka, } \\
\text { TAD, Chair }\end{array}$ & $\begin{array}{l}\text { TriHealth Heart Institute- } \\
\text { Medical Director, Cardiac } \\
\text { Surgery }\end{array}$ & None & None & None & None & None & None & None \\
\hline $\begin{array}{l}\text { Rick A. Nishimura, } \\
\text { VHD, Chair }\end{array}$ & $\begin{array}{l}\text { Mayo Clinic, Division of } \\
\text { Cardiovascular Disease- } \\
\text { Judd and Mary Morris } \\
\text { Leighton Professor of } \\
\text { Medicine }\end{array}$ & None & None & None & None & None & None & None \\
\hline $\begin{array}{l}\text { Mark A. Creager, } \\
\text { TAD Liaison }\end{array}$ & $\begin{array}{l}\text { Dartmouth-Hitchcock Medical } \\
\text { Center-Director, Heart and } \\
\text { Vascular Center and Geisel } \\
\text { School of Medicine at } \\
\text { Dartmouth-Professor of } \\
\text { Medicine }\end{array}$ & None & None & None & None & None & None & None \\
\hline $\begin{array}{l}\text { Robert A. Guyton, } \\
\text { VHD Liaison }\end{array}$ & $\begin{array}{l}\text { Emory Healthcare-Professor } \\
\text { and Chief, Division of } \\
\text { Cardiothoracic Surgery }\end{array}$ & - Medtronic $\dagger$ & None & None & None & None & None & Recused \\
\hline $\begin{array}{l}\text { Eric M. Isselbacher, } \\
\text { TAD }\end{array}$ & $\begin{array}{l}\text { Massachusetts General } \\
\text { Hospital- } \\
\text { Co-Director Thoracic Aortic } \\
\text { Center; Harvard Medical } \\
\text { School-Associate Professor } \\
\text { of Medicine }\end{array}$ & None & None & None & None & None & None & None \\
\hline $\begin{array}{l}\text { Lars G. Svensson, } \\
\text { TAD }\end{array}$ & $\begin{array}{l}\text { Cleveland Clinic, Heart and } \\
\text { Vascular Institute- } \\
\text { Chairman; Cleveland Clinic } \\
\text { Lerner College of Medicine } \\
\text { of Case Western Reserve } \\
\text { University_Professor of } \\
\text { Surgery }\end{array}$ & None & None & None & None & - Posthorax & None & Recused \\
\hline $\begin{array}{l}\text { Robert O. Bonow, } \\
\text { VHD }\end{array}$ & $\begin{array}{l}\text { Northwestern University } \\
\text { Feinberg School of } \\
\text { Medicine-Goldberg } \\
\text { Distinguished Professor of } \\
\text { Cardiology }\end{array}$ & None & None & None & None & None & None & None \\
\hline $\begin{array}{l}\text { Thoralf M. } \\
\text { Sundt III, VHD }\end{array}$ & $\begin{array}{l}\text { Massachusetts General } \\
\text { Hospital—Chief, Division of } \\
\text { Cardiac Surgery; Harvard } \\
\text { Medical School-Professor } \\
\text { of Surgery }\end{array}$ & None & None & None & $\begin{array}{l}\text { - Edwards } \\
\text { LifeScience- } \\
\text { Partner trial (PI) } \\
\text { - Medtronic-Perigon } \\
\text { trial (PI) }\end{array}$ & None & None & Recused \\
\hline
\end{tabular}

This table represents the relationships of committee members with industry and other entities that were determined to be relevant to this document. These relationships were reviewed and updated in conjunction with all meetings and/or conference calls of the writing committee during the document development process. The table does not necessarily reflect relationships with industry at the time of publication. A person is deemed to have a significant interest in a business if the interest represents ownership of $\geq 5 \%$ of the voting stock or share of the business entity, or ownership of $\geq \$ 5000$ of the fair market value of the business entity; or if funds received by the person from the business entity exceed $5 \%$ of the person's gross income for the previous year. Relationships that exist with no financial benefit are also included for the purpose of transparency. Relationships in this table are modest unless otherwise noted. According to the ACC/AHA, a person has a relevant relationship IF: a) the relationship or interest relates to the same or similar subject matter, intellectual property or asset, topic, or issue addressed in the document; or b) the company/entity (with whom the relationship exists) makes a drug, drug class, or device addressed in the document, or makes a competing drug or device addressed in the document; or c) the person or a member of the person's household has a reasonable potential for financial, professional, or other personal gain or loss as a result of the issues/content addressed in the document. ACC, American College of Cardiology; AHA, American Heart Association; $P I$, principal investigator; $T A D$, thoracic aortic disease; $V H D$, valvular heart disease. $*$ Writing committee members are required to recuse themselves from voting on sections to which their specific relationships with industry and other entities may apply. †Significant relationship. 
APPENDIX 2. Reviewer relationships with industry and other entities (relevant)—surgery for aortic dilatation in patients with bicuspid aortic valves: A statement of clarification from the ACC/AHA Task Force on Clinical Practice Guidelines (June 2015)

\begin{tabular}{|c|c|c|c|c|c|c|c|c|}
\hline Reviewer & Representation & Employment & Consultant & $\begin{array}{r}\text { Speaker } \\
\text { bureau }\end{array}$ & $\begin{array}{c}\text { Ownership/ } \\
\text { partnership/ } \\
\text { principal }\end{array}$ & $\begin{array}{l}\text { Personal } \\
\text { research }\end{array}$ & $\begin{array}{c}\text { Institutional, } \\
\text { organizational, } \\
\text { or other } \\
\text { financial } \\
\text { benefit } \\
\end{array}$ & $\begin{array}{l}\text { Expert } \\
\text { witness }\end{array}$ \\
\hline $\begin{array}{r}\text { David H. } \\
\text { Adams }\end{array}$ & $\begin{array}{l}\text { Official } \\
\text { reviewer- } \\
\text { AATS }\end{array}$ & $\begin{array}{l}\text { The Mount Sinai Medical } \\
\text { Center-Marie-Josee } \\
\text { and Henry R. Kravis } \\
\text { Professor; Chairman, } \\
\text { Department of } \\
\text { Cardiothoracic Surgery }\end{array}$ & $\begin{array}{l}\text { - Edward } \\
\text { Lifesciences* } \\
\text { - Medtronic* }\end{array}$ & None & None & None & None & None \\
\hline $\begin{array}{l}\text { Albert T. } \\
\text { Cheung }\end{array}$ & $\begin{array}{l}\text { Official } \\
\text { reviewer- } \\
\text { SCA }\end{array}$ & $\begin{array}{l}\text { Stanford University } \\
\text { School of Medicine- } \\
\text { Professor, Department } \\
\text { of Anesthesiology; } \\
\text { Division Chief, } \\
\text { Cardiothoracic } \\
\text { Anesthesiology; } \\
\text { Program Director, } \\
\text { Adult Cardiothoracic } \\
\text { Anesthesiology }\end{array}$ & - Covidien & None & None & None & None & None \\
\hline $\begin{array}{l}\text { Michael D. } \\
\text { Dake }\end{array}$ & $\begin{array}{l}\text { Official } \\
\text { reviewer- } \\
\text { SIR }\end{array}$ & $\begin{array}{l}\text { Stanford University } \\
\text { School of Medicine, } \\
\text { Cardiothoracic } \\
\text { Surgery-Chief, } \\
\text { Interventional } \\
\text { Radiology }\end{array}$ & $\begin{array}{l}\text { - Abbott Vascular } \\
\text { - CR Bard } \\
\text { - Cook Medical* } \\
\text { - Gore* } \\
\text { - Medtronic }\end{array}$ & None & None & None & None & None \\
\hline $\begin{array}{l}\text { Mario J. } \\
\text { Garcia }\end{array}$ & $\begin{array}{l}\text { Official } \\
\text { reviewer- } \\
\text { AHA }\end{array}$ & $\begin{array}{l}\text { Montefiore Medical } \\
\text { Center-Albert Einstein } \\
\text { College of Medicine- } \\
\text { Chief, Division of } \\
\text { Cardiology }\end{array}$ & None & None & None & - Medtronic $\dagger$ & None & None \\
\hline $\begin{array}{l}\text { Steven A. } \\
\text { Goldstein }\end{array}$ & $\begin{array}{l}\text { Official } \\
\text { reviewer- } \\
\text { ASE }\end{array}$ & $\begin{array}{l}\text { Washington Hospital } \\
\text { Center-Director, } \\
\text { Noninvasive } \\
\text { Cardiology Laboratory }\end{array}$ & None & None & None & None & None & None \\
\hline $\begin{array}{l}\text { Antionette S. } \\
\text { Gomes }\end{array}$ & $\begin{array}{l}\text { Official } \\
\text { reviewer- } \\
\text { AHA }\end{array}$ & $\begin{array}{l}\text { UCLA School of } \\
\text { Medicine-Professor, } \\
\text { Radiology and } \\
\text { Medicine }\end{array}$ & None & None & None & None & None & None \\
\hline Anuj Gupta & $\begin{array}{l}\text { Official } \\
\text { reviewer- } \\
\text { ACC Board } \\
\text { of Governors }\end{array}$ & $\begin{array}{l}\text { University of Maryland } \\
\text { School of Medicine- } \\
\text { Assistant Professor of } \\
\text { Medicine and Director, } \\
\text { Cardiac Catheterization } \\
\text { Laboratory }\end{array}$ & None & None & None & 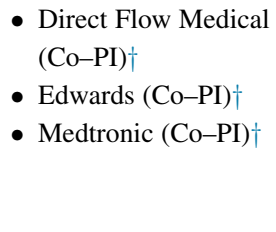 & 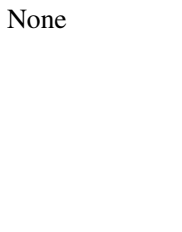 & None \\
\hline $\begin{array}{r}\text { Jonathan L. } \\
\text { Halperin }\end{array}$ & $\begin{array}{l}\text { Official } \\
\text { reviewer- } \\
\text { ACC/AHA } \\
\text { Task Force on } \\
\text { Clinical } \\
\text { Practice } \\
\text { Guidelines }\end{array}$ & $\begin{array}{l}\text { Mt. Sinai Medical } \\
\text { Center-Professor of } \\
\text { Medicine }\end{array}$ & - Medtronic & None & None & None & None & None \\
\hline $\begin{array}{l}\text { Clifford J. } \\
\text { Kavinsky }\end{array}$ & & $\begin{array}{l}\text { Rush-Presbyterian-St. } \\
\text { Luke's Medical }\end{array}$ & None & None & None & None & None & None \\
\hline
\end{tabular}


Institutional,

organizational,

or other

financial Expert

Ownership/

Consultant bureau principal

Personal

benefit

witness

\begin{tabular}{|c|c|c|c|c|c|c|c|c|}
\hline Reviewer & Representation & Employment & Consultant & bureau & principal & research & benefit & witness \\
\hline & $\begin{array}{l}\text { Official } \\
\text { reviewer- } \\
\text { SCAI }\end{array}$ & $\begin{array}{l}\text { Center-Training } \\
\text { Director }\end{array}$ & & & & & & \\
\hline Scott Kinlay & $\begin{array}{l}\text { Official } \\
\text { reviewer- } \\
\text { SVM }\end{array}$ & $\begin{array}{l}\text { VA Boston Healthcare } \\
\text { System-Director, } \\
\text { Cardiac Catheterization } \\
\text { Lab }\end{array}$ & None & None & None & - Medtronic* & None & None \\
\hline $\begin{array}{c}\text { Michael J. } \\
\text { Mack }\end{array}$ & $\begin{array}{l}\text { Official } \\
\text { reviewer- } \\
\text { ACC Board } \\
\text { of Trustees }\end{array}$ & $\begin{array}{l}\text { The Heart Hospital Baylor } \\
\text { Plano-Director }\end{array}$ & None & None & None & $\begin{array}{l}\text { - Abbott Vascular } \dagger \\
\text { - Edwards } \dagger\end{array}$ & None & None \\
\hline $\begin{array}{l}\text { Steven R. } \\
\text { Messé }\end{array}$ & $\begin{array}{l}\text { Official } \\
\text { reviewer- } \\
\text { ASA }\end{array}$ & $\begin{array}{l}\text { University of } \\
\text { Pennsylvania- } \\
\text { Department of } \\
\text { Neurology }\end{array}$ & None & None & None & None & None & None \\
\hline Eric Roselli & $\begin{array}{l}\text { Official } \\
\text { reviewer- } \\
\text { STS }\end{array}$ & $\begin{array}{l}\text { Cleveland Clinic- } \\
\text { Director of the Aortic } \\
\text { Center, Heart and } \\
\text { Vascular Institute }\end{array}$ & $\begin{array}{l}\text { - Edwards* } \\
\text { - Medtronic* } \\
\text { - Sorin* }\end{array}$ & None & None & None & None & None \\
\hline $\begin{array}{l}\text { Frank J. } \\
\text { Rybicki }\end{array}$ & $\begin{array}{l}\text { Official } \\
\text { reviewer- } \\
\text { ACR }\end{array}$ & $\begin{array}{l}\text { The Ottawa Hospital- } \\
\text { Chief of Medical } \\
\text { Imaging and Professor } \\
\text { and Chair of Radiology }\end{array}$ & None & None & None & - Toshiba & None & None \\
\hline $\begin{array}{l}\text { Richard D. } \\
\text { White }\end{array}$ & $\begin{array}{l}\text { Official } \\
\text { reviewer- } \\
\text { AHA }\end{array}$ & $\begin{array}{l}\text { The Ohio State University } \\
\text { Medical Center- } \\
\text { Professor and } \\
\text { Chairman, Cardiology }\end{array}$ & None & None & None & None & None & None \\
\hline
\end{tabular}

This table represents the relationships of reviewers with industry and other entities that were disclosed at the time of peer review and determined to be relevant to this document. It does not necessarily reflect relationships with industry at the time of publication. A person is deemed to have a significant interest in a business if the interest represents ownership of $\geq 5 \%$ of the voting stock or share of the business entity, or ownership of $\geq \$ 5000$ of the fair market value of the business entity; or if funds received by the person from the business entity exceed $5 \%$ of the person's gross income for the previous year. A relationship is considered to be modest if it is less than significant under the preceding definition. Relationships that exist with no financial benefit are also included for the purpose of transparency. Relationships in this table are modest unless otherwise noted. Names are listed in alphabetical order within each category of review. According to the ACC/AHA, a person has a relevant relationship IF: a) the relationship or interest relates to the same or similar subject matter, intellectual property or asset, topic, or issue addressed in the document; or b) the company/entity (with whom the relationship exists) makes a drug, drug class, or device addressed in the document, or makes a competing drug or device addressed in the document; or c) the person or a member of the person's household has a reasonable potential for financial, professional, or other personal gain or loss as a result of the issues/content addressed in the document. AATS, The American Association for Thoracic Surgery; ACC, American College of Cardiology; ACR, American College of Radiology; AHA, American Heart Association; ASE, American Society of Echocardiography; ASA, American Stroke Association; PI, principal investigator; SCA, Society of Cardiovascular Anesthesiologists; SCAI, Society for Cardiovascular Angiography and Interventions; SIR, Society of Interventional Radiology; STS, Society of Thoracic Surgeons; SVM, Society of Vascular Medicine. *Significant relationship. †No financial benefit. 